\title{
Internal reforming on Metal supported SOFCs
}

\author{
Hagen, A.; Sun, X.; Sudireddy, B. R.; Persson, Å. H.
}

\section{Published in:}

ECS Transactions

Link to article, DOI:

10.1149/09101.0867ecst

Publication date:

2019

Document Version

Peer reviewed version

Link back to DTU Orbit

Citation (APA):

Hagen, A., Sun, X., Sudireddy, B. R., \& Persson, Å. H. (2019). Internal reforming on Metal supported SOFCs. ECS Transactions, 91(1), 867-876. https://doi.org/10.1149/09101.0867ecst

\section{General rights}

Copyright and moral rights for the publications made accessible in the public portal are retained by the authors and/or other copyright owners and it is a condition of accessing publications that users recognise and abide by the legal requirements associated with these rights.

- Users may download and print one copy of any publication from the public portal for the purpose of private study or research.

- You may not further distribute the material or use it for any profit-making activity or commercial gain

- You may freely distribute the URL identifying the publication in the public portal

If you believe that this document breaches copyright please contact us providing details, and we will remove access to the work immediately and investigate your claim. 


\title{
Internal reforming on Metal supported SOFCs
}

\author{
A. Hagen ${ }^{a}$, X. Sun ${ }^{a}$, B. R. Sudireddya, and Å. H. Persson ${ }^{a}$ \\ ${ }^{a}$ Department of Energy Conversion and Storage, Technical University of Denmark, Risø \\ Campus, 4000 Roskilde, Denmark
}

\begin{abstract}
Metal supported solid oxide fuel cell technology (MSC) has a significant potential for mobile applications, due to high electrical efficiencies, fuel flexibility, cheap materials, and mechanical robustness. The MSC concept in the current study relies on ceramic, scalable processing methodology. Two MSC generations with different anodes, one with a FeCr-ScYSZ-based anode cermet backbone and one with a titanate based anode backbone, which both were infiltrated with $\mathrm{CGO}$ and $\mathrm{Ni}$ electro catalysts, were tested using methane containing fuel. It was found that the internal reforming activity of the anodes is reduced as compared to stateof-the-art Ni-cermet anodes, due to the lower $\mathrm{Ni}$ content in the anodes of the MSCs. Still, power densities of ca. $0.22 \mathrm{~W} / \mathrm{cm}^{2}$ were obtained at $650{ }^{\circ} \mathrm{C}$ in a methane/steam fuel and long-term tests at medium to high fuel utilization were demonstrated on the titanate based MSC.
\end{abstract}

\section{Introduction}

Metal supported solid oxide fuel cell (SOFC) technology (MSC) has attractive features for mobile / transport applications. It combines the high electrical efficiencies and fuel flexibility of SOFCs with cheap materials and higher mechanical robustness of the MSC concept. MSC concepts include for example perforated ferritic steel supports (1) or tape cast metal supports (2).

MSC concepts with tape cast supports have demonstrated high power density of 1.2 $\mathrm{W} / \mathrm{cm}^{2}$ at $750{ }^{\circ} \mathrm{C}(2)$. Furthermore, such cells provided good long-term stability under constant operation over up to ca. $3000 \mathrm{~h}$ with hydrogen fuel $(2,3)$. Challenges include corrosion issues and $\mathrm{Ni}$ interdiffusion, particularly at high steam content, which is the case when operating at high fuel utilization (4). In order to overcome these degradation mechanisms, alternative anodes were developed. Promising alternative anodes are based on titanates, for example lanthanum strontium iron nickel titanate (LSFNT). MSCs with such anodes showed a reduced peak performance compared to the first generation by ca. $30 \%(5,6)$. On the other hand, they were still more active than other alternative anodes to state-of-the-art (SoA) Ni-cermets. Initial durability tests using hydrogen fuel showed promising results. The improved stability were ascribed an improved corrosion resistance (7).

For mobile and stationary applications, not only hydrogen but also carbon containing fuels are interesting in order to take advantage of the fuel flexibility of SOFCs. However, the knowledge about the behavior of MSCs in for example methane containing fuels are 
lacking. The current study investigated performance and durability of MSCs in methane/steam fuel. Special interest is on the activity of the anodes for internal reforming.

\section{Experimental}

Two types of MSCs were tested, one version with an anode backbone of FeCr-ScYSZ (denoted $\mathrm{FeCr}$ MSC) and one with a $\mathrm{FeCr}-\mathrm{La}_{0.4} \mathrm{Sr}_{0.4} \mathrm{Fe}_{0.03} \mathrm{Ni}_{0.03} \mathrm{Ti}_{0.94} \mathrm{O}_{3}$ (LSFNT) based anode backbone (denoted LSFNT MSC). The cell design is schematically illustrated in the Figure 1. Both versions are based on a FeCr support. The metal support, anode backbone and electrolyte layers were fabricated using tape casting. The layers were laminated and sintered in reducing environment at temperatures between $1200{ }^{\circ} \mathrm{C}-1300$ ${ }^{\circ} \mathrm{C}$, to form the half-cell. Subsequently, the anode backbone was infiltrated with aqueous metal nitrates of $\mathrm{Ni}, \mathrm{Ce}$ and $\mathrm{Gd}$ to form the Ni-GDC electro catalyst upon subsequent heat treatment. The procedure for infiltration is described elsewhere [8]. The ratio of $\mathrm{Ni}$ to GDC was $10: 90$ by weight. After three cycles of infiltration, the electro catalyst loading was $0.008-0.01 \mathrm{~g} / \mathrm{cm}^{2}$ resulting in ca. $0.0008-0.001 \mathrm{~g} / \mathrm{cm}^{2}$ of Ni. After the integration of electro catalyst, a $\mathrm{Ce}_{0.9} \mathrm{Gd}_{0.1} \mathrm{O}_{1.95}$ barrier layer was deposited using physical vapor deposition, to prevent the reaction between electrolyte and cathode. Finally, the $\left(\mathrm{La} 0.6 \mathrm{Sr}_{0.4}\right)_{0.99} \mathrm{CoO}_{3-\delta}$ (LSC) cathode was deposited using screen printing. The cathode was sintered in-situ during startup, prior to the electrochemical cell testing [9].

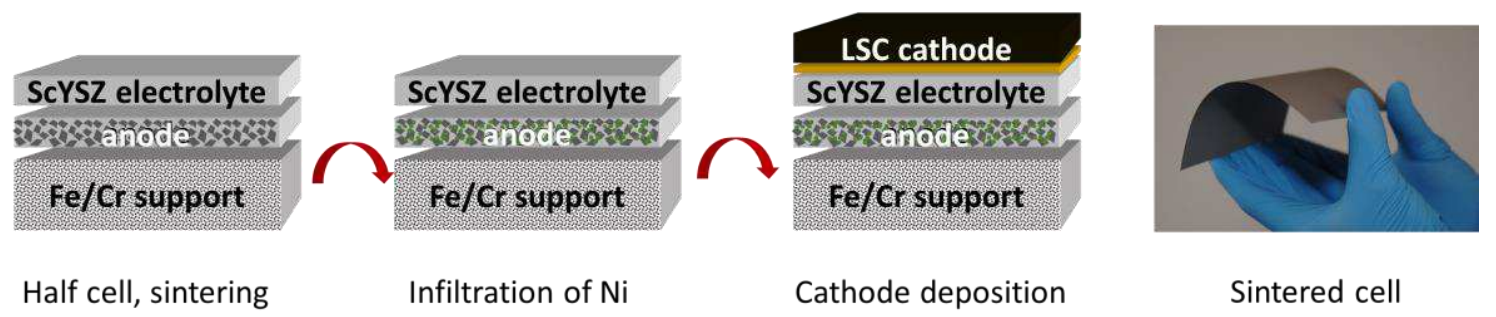

Figure 1. Illustration of MSC types

The cells were placed in a ceramic test house, $\mathrm{Ni}$ and $\mathrm{Au}$ meshes were used as contact and current collector components on the anode and cathode side, respectively. The cells were sealed at their edges using glass.

The tests were initiated by heating to $800^{\circ} \mathrm{C}$ with a heating rate of $1{ }^{\circ} \mathrm{C} / \mathrm{min}$ and held for 5 hours at $800{ }^{\circ} \mathrm{C}$ for in-situ sintering of the cathode. Initial iV curves and electrochemical impedance spectra (EIS) were recorded from 750 to $650{ }^{\circ} \mathrm{C}$, with different hydrogen/steam fuel ratios (and with methane/steam fuel), according to a standardized protocol (denoted as fingerprint). One LSFNT cell was set to durability conditions with hydrogen and another with methane/steam at $650{ }^{\circ} \mathrm{C}$. 


\section{Results and discussion}

$\underline{\text { Initial performances }}$

The initial performance of all cells was characterized by iV curves in hydrogen (with $20 \%$ steam) and in methane/steam fuel. The use of hydrogen serves the verification of the test setup, i.e. if the theoretic open circuit voltage (OCV) is reached $(1041 \mathrm{mV}$ under the current conditions in hydrogen with $20 \%$ steam), intact contacting of the cell in the setup, and the comparison between all cell types and generations. Deviation from this OCV would for example indicate a leaky test setup. When methane is fueled directly, steam is added to provide a reforming agent and with a ratio, which should prevent carbon formation. Typically, a steam to methane ratio of two is applied. Under these conditions, methane is reformed (equation [1]) and the water gas shift reaction occurs (equation [2]). The resulting equilibrium gas mixture consists of $\mathrm{CO}, \mathrm{CO}_{2}, \mathrm{H}_{2} \mathrm{O}$, and $\mathrm{H}_{2}$, yielding an OCV of $1049 \mathrm{mV}$ at $650{ }^{\circ} \mathrm{C}$ (based on the Nernst equation). Deviations from this OCV value would indicate incomplete methane conversion, i.e. a gas composition not corresponding to equilibrium.

$$
\begin{aligned}
& \mathrm{CH}_{4}+\mathrm{H}_{2} \mathrm{O} \rightleftharpoons \mathrm{CO}+3 \mathrm{H}_{2} \\
& \mathrm{CO}+\mathrm{H}_{2} \mathrm{O} \rightleftharpoons \mathrm{CO}_{2}+\mathrm{H}_{2}
\end{aligned}
$$

Figure 2 shows the $\mathrm{iV}$ curves of the $\mathrm{FeCr}$ cell at $650{ }^{\circ} \mathrm{C}$. The measured $\mathrm{OCV}$ in hydrogen with $20 \%$ steam was $1040 \mathrm{mV}$, i.e. very close to the theoretic value, and thus confirming that the cell behaves as expected. The maximum power output was $0.5 \mathrm{~W} / \mathrm{cm}^{2}$ at $0.75 \mathrm{~A} / \mathrm{cm}^{2}$. When using methane / steam fuel, the OCV was only $886 \mathrm{mV}$ and thus significantly lower than the theoretic value of $1049 \mathrm{mV}$. This is a clear indication for an incomplete methane conversion. The reason is most probably the much smaller Niconcentration in the anode as compared to SoA anode supported SOFCs with a Ni/YSZ cermet anode. Such cells contain ca. $3.5 \mathrm{~g} / \mathrm{cm}^{2} \mathrm{Ni}$ in the active anode (in addition, $\mathrm{Ni}$ is also present in the thick anode support layer) and contain thus a factor of more than thousand more Ni than the MSCs in this study. The obtained value of $886 \mathrm{mV}$ would correspond to ca. 3.5\% methane conversion, only. Such low conversion translates directly into small concentrations of hydrogen (and CO) for the electrochemical reactions and leads thus to a very fast fuel starvation during iV curve recording (see Figure 2).

Figure 3 shows the initial performance of two LSFNT MSCs in hydrogen/steam and of one LSFNT MSCs in hydrogen/steam and in methane/steam fuel at $650{ }^{\circ} \mathrm{C}$. The OCV in hydrogen with $20 \%$ steam was $1038 \mathrm{mV}$, which is only a $3 \mathrm{mV}$ difference to the theoretic voltage. This result confirms a tight setup, i.e. intact sealing. The maximum power output was $0.4 \mathrm{~W} / \mathrm{cm}^{2}$ at a current density of $0.6 \mathrm{~A} / \mathrm{cm}^{2}$. Both cells behaved very similarly, indicating a good reproducibility. The power output was thus smaller than with the $\mathrm{FeCr}$ cell, which confirms earlier findings $(5,6)$. Using methane/steam fuel on the LSFNT cell, again a smaller than theoretic OCV was observed, only $944 \mathrm{mV}$. The lower OCV is again due to the incomplete conversion of methane. The measured value corresponds to a methane conversion of ca. $17 \%$, which is still better than what was found testing the $\mathrm{FeCr}$ cell with the same fuel. Consequently, both MSC anodes with a smaller content of $\mathrm{Ni}\left(0.8-1 \mathrm{mg} / \mathrm{cm}^{2}\right)$, are not sufficiently active for the internal methane reforming reaction (and probably also the water gas shift reaction). The higher methane 
conversion as compared to the $\mathrm{FeCr}$ MSC could be due to a potential catalytic effect of $\mathrm{Ni}$ in the LSFNT or due to more active Ni-LSFNT-backbone interactions. For operating this fuel cell, it means that not as much hydrogen and $\mathrm{CO}$ are formed for the electrochemical reaction as compared to SoA Ni/YSZ anodes and that the resulting real fuel utilization is higher and fuel starvation might occur, which is also visible in the $\mathrm{iV}$ curve for methane /steam fuel in Figure 3. The curve is bending down already around 0.4 $\mathrm{A} / \mathrm{cm}^{2}$, while there is no sign for fuel starvation in hydrogen /steam fuel at $0.6 \mathrm{~A} / \mathrm{cm}^{2}$ and beyond. On the other hand, the electrochemical behavior in terms of area specific resistance (ASR) in the linear region of the iV curve is similar in both fuels. The values are $0.85 \Omega \mathrm{cm}^{2}$ and $0.86 \Omega \mathrm{cm}^{2}$ in hydrogen/steam and methane/steam, respectively. The LSFNT MSC is thus a good candidate for application and the reduced performance in hydrogen as compared to the $\mathrm{FeCr}$ cell is compensated by the better performance in methane.

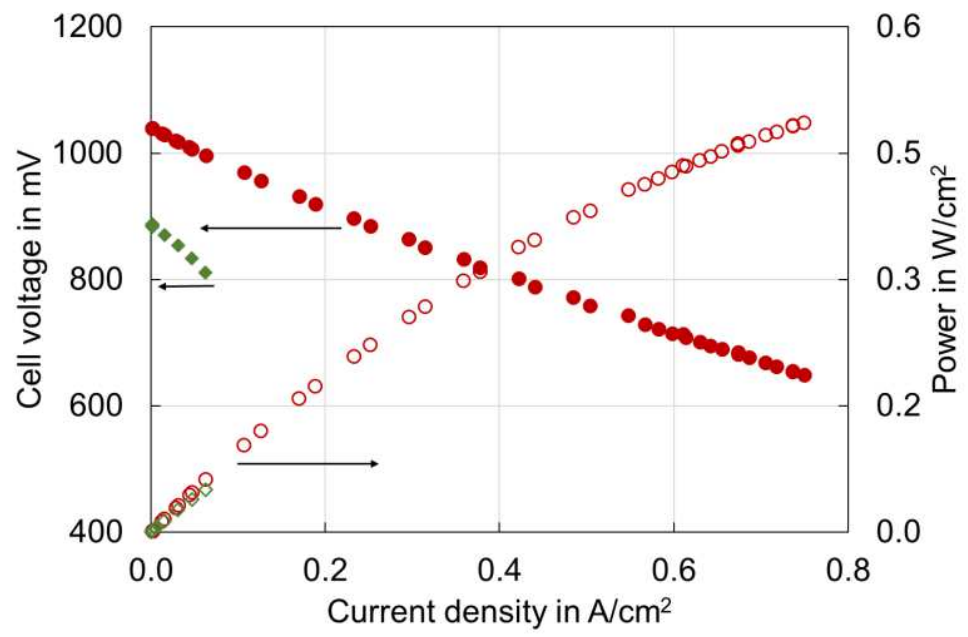

Figure 2. FeCr MSC, iV curves (full symbols, left axis) and power curves (open symbols, right axis) at $650{ }^{\circ} \mathrm{C}$, air to the cathode and either hydrogen $/ 20 \%$ steam (red circles) or methane/steam with a ratio of $1 / 2$ (green rhombs)

In order to enable or improve the performance of the two cell types for use of methane containing fuel, a pre-reformer could be installed in the system or the Ni loading of the anodes increased through more infiltration cycles or higher solid loading of the infiltrate solution. 


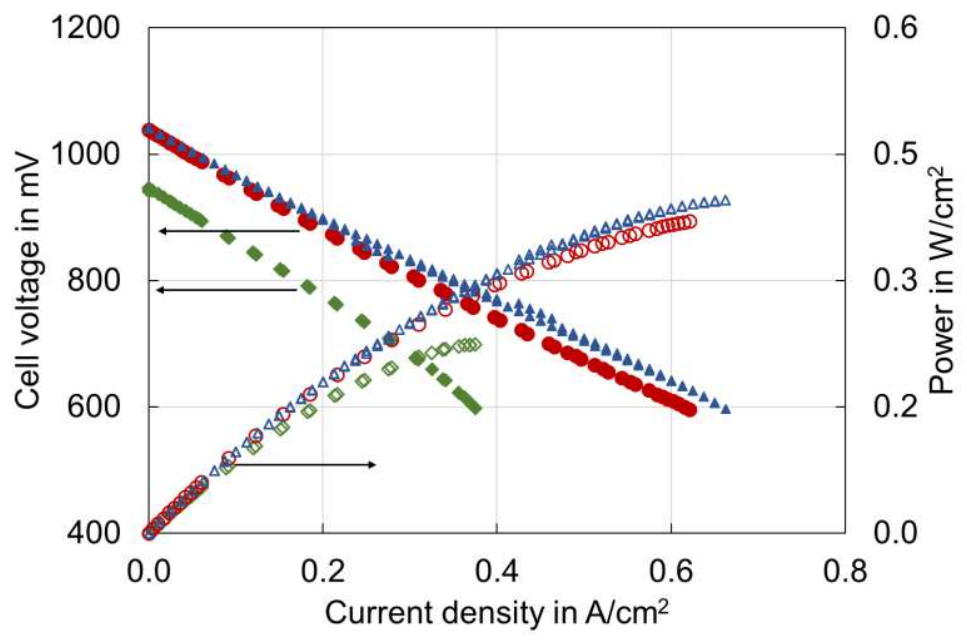

Figure 3. LSFNT MSC, Ii curves (full symbols, left axis) and power curves (open symbols, right axis) at $650{ }^{\circ} \mathrm{C}$, air to the cathode and either hydrogen $/ 20 \%$ steam (red circles and blue triangles) or methane/steam with a ratio of $1 / 2$ (green rhombs)

\section{Electrochemical evaluation}

The iV curves, recorded during the initial characterization in either hydrogen or methane containing fuel, revealed different behaviors of the two MSC types, FeCr and LSFNT. The results were therefore evaluated using the EIS fingerprint test protocol, which included change of gas compositions to cathode and anode.

Figure 4 and Figure 5 show the EIS recorded in hydrogen and methane containing fuels on the both MSC types. Significant differences of the polarization resistances are observed when the fuel is changed, while the serial resistances remained the same. On the $\mathrm{FeCr} \mathrm{MSC}$, the polarization resistance increased in the methane/steam vs. hydrogen/steam fuel, in the low and medium frequency range (see Figure 4). These results indicate increased resistance of the electrode as well as transport processes when fueling methane directly.

On the other hand, the polarization resistance was nearly the same in both fuels on the LSFNT cell (see Figure 5). This result confirms the ASR values, which were obtained from the iV curves and which were also very similar in both fuels (see Figure 3). Obviously, electrochemical processes, including transport of ions and electrons occur similarly in both fuels. The internal methane reforming - even though not complete produces hydrogen (and CO), which behave as if hydrogen is fueled directly. Only in a regime, where not sufficient hydrogen is produced due to the incomplete methane reforming, the LSFNT MSC experiences lack of fuel and increase of ASR (see Figure 3, higher current densities) as compared to the direct fueling of hydrogen. 

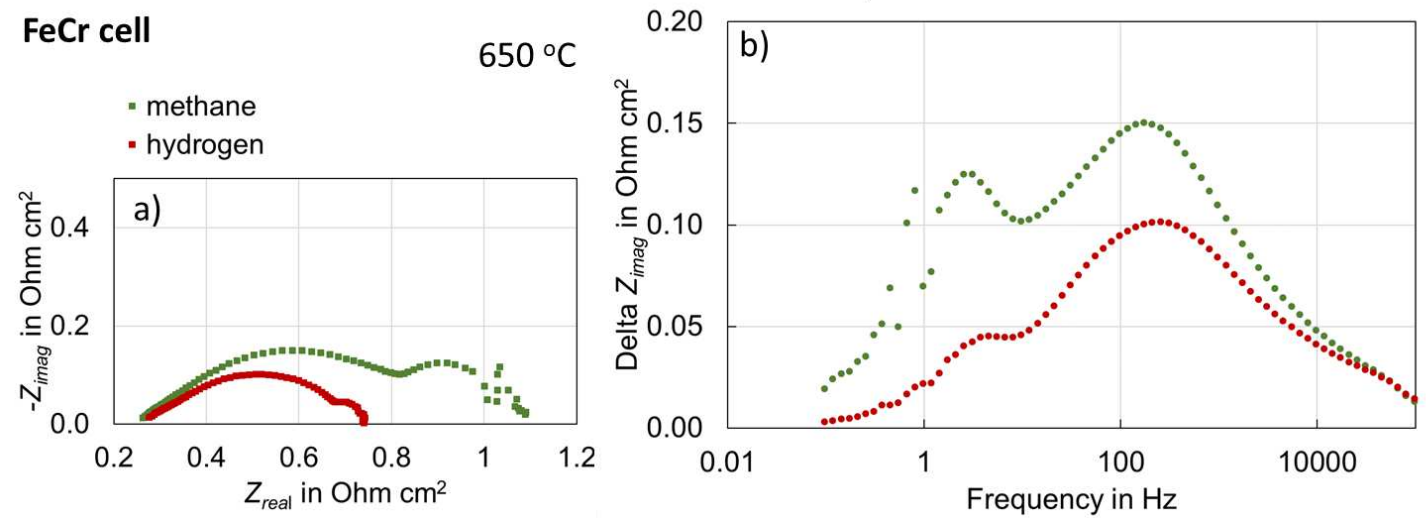

Figure 4. EIS on the FeCr MSC at $650{ }^{\circ} \mathrm{C}$ and $\mathrm{OCV}$, air to the cathode and hydrogen $/ 20 \%$ steam (red symbols) or methane/steam $=1 / 2$ to the anode (green symbols) a) Nyquist and b) Bode plot.
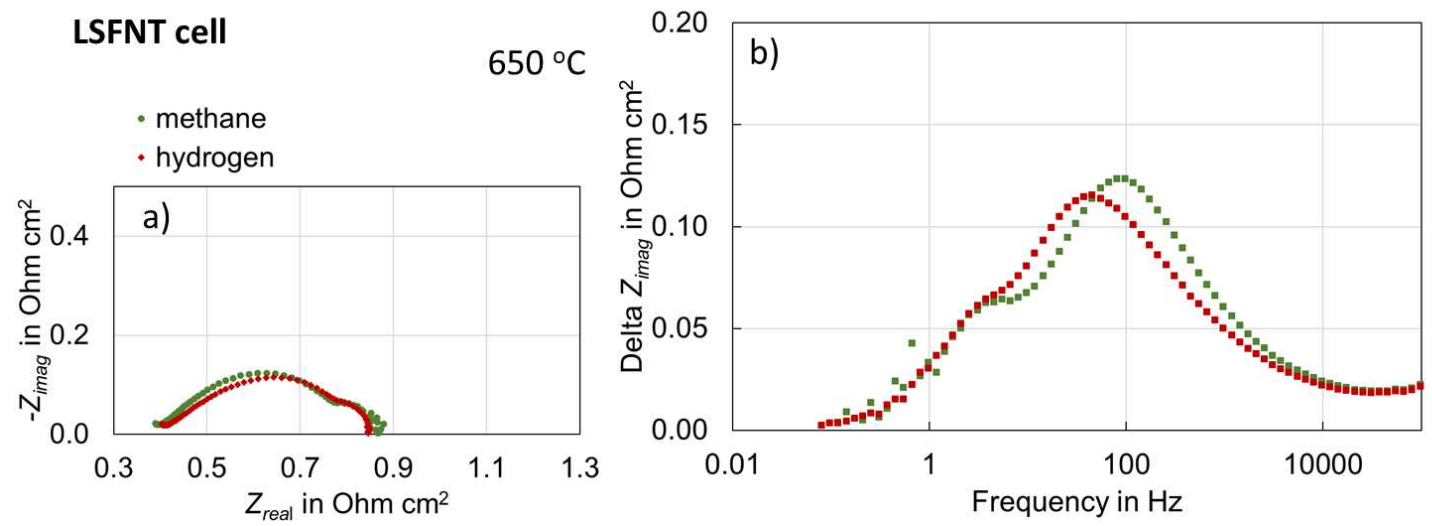

Figure 5. EIS on the LSFNT MSC at $650{ }^{\circ} \mathrm{C}$ and $\mathrm{OCV}$, air to the cathode and hydrogen $/ 20 \%$ steam (red symbols) or methane/steam $=1 / 2$ to the anode (green symbols) a) Nyquist and b) Bode plot.

A means to identify specific electrodes and processes is to record EIS under different fuel-to-anode and oxygen-partial-pressure-to cathode compositions and to observe the changes of EIS. Figure 6 shows the results on both MSCs. For a fast visualization of the affected processes in the EIS, a simple difference between the spectra (Bode plots) was calculated and plotted.

When the cathode gas was changed between air und oxygen, the impedance in the frequency region around $100 \mathrm{~Hz}$ was affected for both MSC types (see Figure 6, red symbols). This indicates that cathode processes are involved in this frequency region and that those are similar in both MSC types, which seems justified because the same cathode type was deposited on both MSC types (LSC). Further, when the degree of humidification of hydrogen to the anode was changed, impedance contributions in the 
frequency ranges of ca. 0.5 and ca. $10 \mathrm{~Hz}$ were affected, on both MSC types. Such low frequency ranges are characteristic for gas conversion and diffusion, respectively. Because both MSC types show similar responses, these two processes seem to proceed in a similar way on the FeCr and the LSFNT MSCs. The chemical composition of the anode backbone seems thus to have a smaller effect as compared to the structure. The two backbones possess similar structures and the infiltration was carried out with the same procedure on both MSCs.

The most distinct difference between the FeCr and the LSFNT MSCs is the response to changing the fuel from hydrogen to methane based compositions (green symbols in Figure 6). Two main processes are affected on the $\mathrm{FeCr}$ MSC, while there is almost no effect on the LSFNT cell. The latter finding is well corresponding with the results of the iV curves and the EIS-Nyquist and Bode plots (Figure 3 and Figure 5).
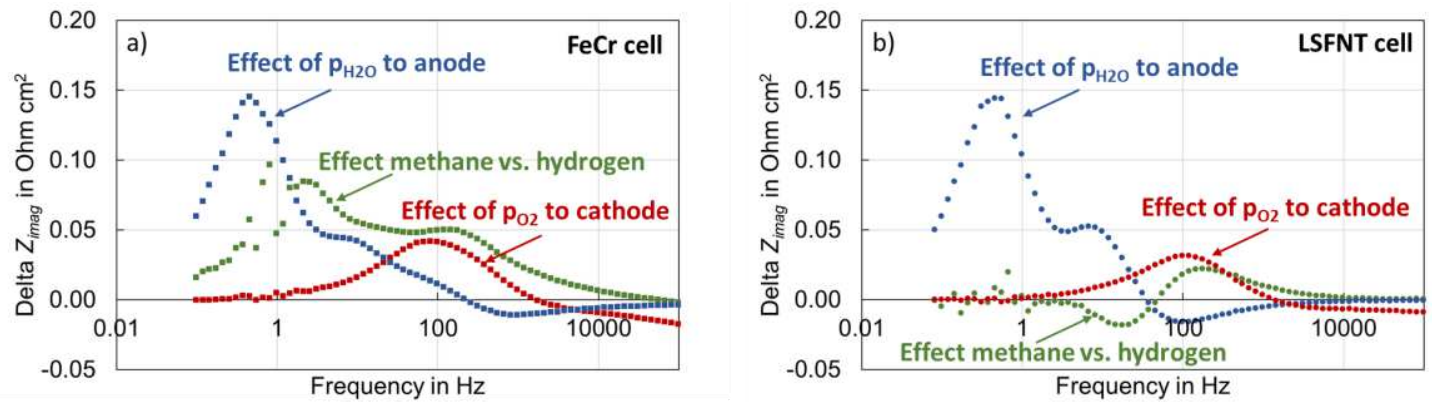

Figure 6. Difference of EIS (Bode plots), $650{ }^{\circ} \mathrm{C}$ and OCV, blue symbols: $20 \%$ steam in hydrogen vs. $4 \%$ steam in hydrogen to anode, green symbols: methane/steam vs. hydrogen $/ 20 \%$ steam to anode, red symbols: air vs. oxygen to cathode, a) on the $\mathrm{FeCr}$ MSC and $b$ ) on the LSFNT MSC.

More specifically, the frequencies around $3 \mathrm{~Hz}$ and ca. 100-140 $\mathrm{Hz}$ change for the $\mathrm{FeCr}$ cell. As already mentioned, low frequency ranges are characteristic for gas diffusion/gas conversion, while anode processes should be responsible for the higher frequency responses. The increase of gas diffusion/conversion impedance can be explained by the severely suppressed methane reforming reaction, leading to insufficient fuel at the anode. In addition, anode reactions are affected when introducing methane/steam fuel, which might be due to the high steam content present when only a small fraction of methane is converted in the reforming reaction.

\section{Durability}

Due to the low initial performance of the FeCr MSC in methane fuel, the durability tests were only carried out with the LSFNT MSCs. Furthermore, the good durability of the $\mathrm{FeCr}$ MSC in hydrogen fuel at low fuel utilization was already demonstrated over $3000 \mathrm{~h}$ in previous studies $(2,3)$.

The LSFNT MSC was tested in hydrogen fuel for 2000 hours, with several interruptions due to technical challenges (see Figure 7, degradation rates in Table I). 
During the testing, the fuel utilization (FU) was successively increased from 10 to 42 , and finally to $70 \%$. The linear cell voltage degradation rates were $5 \% / 1000 \mathrm{~h}$ at $10 \% \mathrm{FU}$ and $6 \% / 1000 \mathrm{~h}$ at $42 \% \mathrm{FU}$. At the highest $\mathrm{FU}$ of $70 \%$, the degradation rate started at ca. $13 \% / 1000 \mathrm{~h}$ during the first ca. $180 \mathrm{~h}$ and started to accelerate afterwards. It thus seems to be a critical FU leading to irreversible degradation of the LSFNT cell with hydrogen fuel.

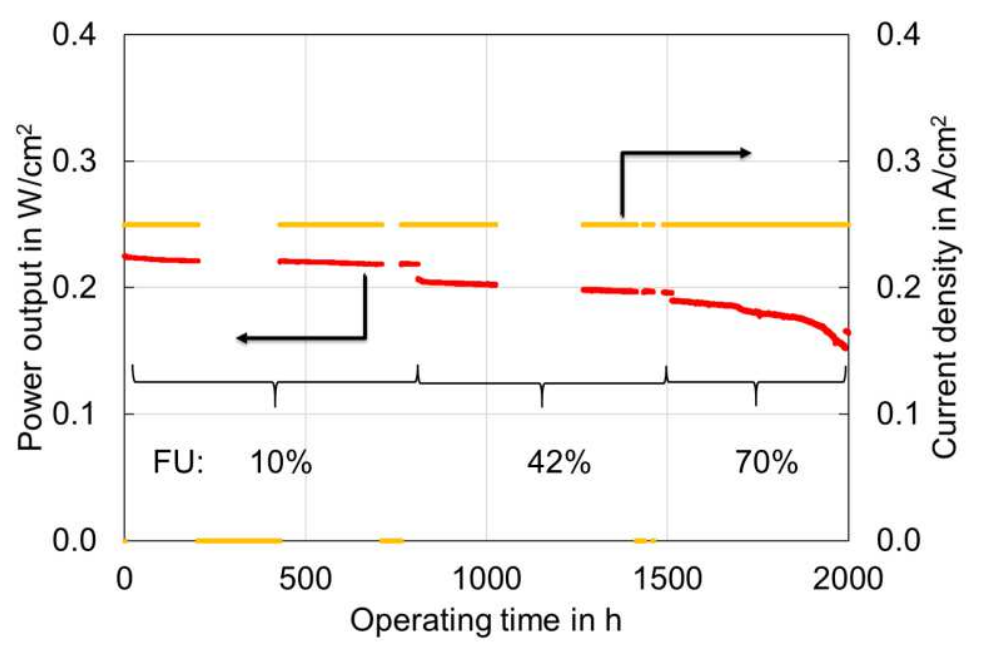

Figure 7. Long-term test of the LSFNT MSC, power output (red curve, left axis), current density (yellow curve, right axis), $650^{\circ} \mathrm{C}$, air to the cathode and hydrogen $/ 20 \%$ steam

Another LSFNT cell was tested for durability in methane/steam fuel. Figure 8 shows the results. For comparison, the flows were adjusted to obtain the same FU as for the case of hydrogen, under the assumption of complete methane reforming, i.e. with the hydrogen content corresponding to the equilibrium. The initial iV curves showed (see Figure 3), that the methane conversion was incomplete. This leads to a smaller hydrogen content and thus a higher, real FU. Table I lists the real FUs for the tests in hydrogen and methane containing fuels.

The test demonstrated for the first time that MSCs can operate in methane/steam fuel - in this case over ca. $120 \mathrm{~h}$. The degradation rate during the first ca. $120 \mathrm{~h}$ was rather high, with ca. $30 \% / 1000 \mathrm{~h}$ (see Table I). This fast degradation can be explained by the high, real FU. Even though the fuel flow was set to yield the same FU as in the test with hydrogen (i.e., $10 \%$, see Figure 7), the real FU was significantly higher. It amounted to ca. $48 \%$ when considering that methane was not completely converted and thus less hydrogen available for the electrochemical reaction. When the FU was further increased, the cell degradation accelerated. These initial durability tests in hydrogen and methane containing fuel indicate that the degradation starts to accelerate at FUs around 50-60\%. Detailed post-test micro structural analysis will be carried out in order to identify the origins of this degradation. 


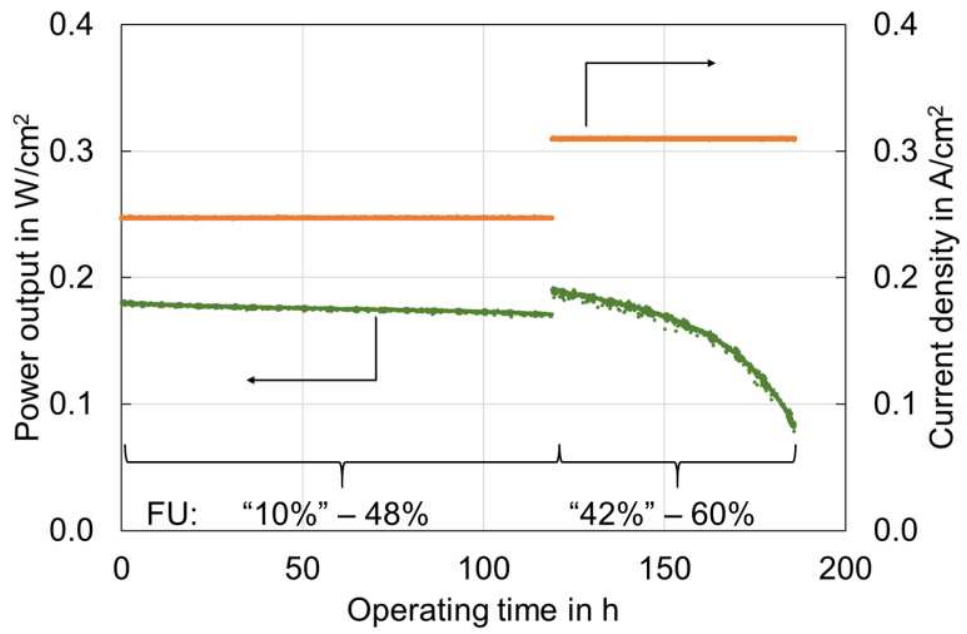

Figure 8. Long-term test of the LSFNT MSC, power output (green curve, left axis), current density (orange curve, right axis), $650{ }^{\circ} \mathrm{C}$, air to the cathode and methane/steam with a ratio of $1 / 2$

TABLE I. FUs for the tests of the LSFNT MSCs in hydrogen or in methane containing fuels and obtained cell voltage degradation rates at $650{ }^{\circ} \mathrm{C}$.

\begin{tabular}{|c|c|c|c|}
\hline Fuel & $\begin{array}{c}\text { FU based on the flows } \\
(\%)\end{array}$ & $\begin{array}{l}\text { FU based on the reduced } \\
\text { methane conversion (\%) }\end{array}$ & $\begin{array}{l}\text { Cell voltage degradation } \\
\text { rate }(\% / 1000 \mathrm{~h})\end{array}$ \\
\hline \multirow[t]{3}{*}{ Hyrogen/steam } & 10 & & 5 \\
\hline & 42 & & 6 \\
\hline & 70 & & 13 \\
\hline \multirow[t]{2}{*}{ Methane/steam } & & 48 & 30 \\
\hline & & 60 & accelerated \\
\hline
\end{tabular}

\section{Summary}

Two types of MSCs were operated in methane/steam fuel, with the aim to investigate the internal reforming behavior of anodes with either FeCr or LSFNT backbones, with infiltrated active $\mathrm{Ni} / \mathrm{CGO}$ particles. As compared to SoA Ni/YSZ anodes, the internal methane reforming is incomplete on the MSC anodes with less Ni content, more than a factor of thousand less than in Ni/YSZ active anode layers. The MSCs with LSFNT backbone showed a higher methane conversion and the formed hydrogen acts in the same way as if fueled directly. On the MSC with a $\mathrm{FeCr}$ backbone, the reforming reaction is strongly suppressed, to an extent that not only gas conversion / diffusion impedance is increased but also the anode reaction impedance as well.

Direct operation of a MSC with LSFNT backbone with methane / steam fuel over in total ca. two hundred hours was demonstrated for the first time. The incomplete methane conversion has to be considered for the calculation of the real FU. The cell was operated at FU around $50 \%$ and higher. The degradation is most probably related to the resulting high steam content. 
If needed in a system context, the reforming activity of the MSCs can be improved by increasing the Ni content in the anode or by adding a pre-reformer prior to the SOFC.

\section{Acknowledgments}

The authors thank K. Brodersen and L. Knudsen for cell manufacture, J. Nielsen and $\mathrm{H}$. Henriksen for very valuable technical assistance for cell testing.

\section{References}

1. R. Leah, A. Bone, E. Hammer, A. Selcuk, M. Rahman, A. Clare, S. Mukerjee and M. Selby, Proceedings of the 13th European SOFC \& SOE Forum, Lucerne, Chapter 02, A0302, pp. 13 (2018).

2. P.T. Blennow, J. Hjelm, T. Klemensø, Å.H. Persson, K. Brodersen, A.K. Srivastava, H.L. Frandsen, M. Lundberg, S. Ramousse and M.B. Mogensen, ECS Transactions, 25 (2) 701-710 (2009).

3. T. Klemensø, J. Nielsen, P. Blennow, Å. H. Persson, T. Stegk, P. Hjalmarsson, B. H. Christensen, S. Sønderby, J. Hjelm, and S. Ramousse, ECS Transactions, 35 (1) 369378 (2011).

4. B. J. McKenna, N. Christiansen, R. Schauperl ,P. Prenninger, J.Nielsen, P. Blennow, T. Klemensø, S. Ramousse, A. Kromp and A. Weber, Fuel Cells, 13 (4), 592-597 (2013).

5. B. R. Sudireddy, J. Nielsen, Å. H. Persson, K. Thyden, K. Brodersen, S. Ramousse, D. Neagu, E. Stefan, J. T. S. Irvine, H.Geisler, A.Weber, G. Reiss, R. Schauperl, J. Rechberger, J. Froitzheim, R. Sachitanand, H. Falk-Windisch, J. E. Svensson, M. W. Lundberg, R. Berger, J.Westlinder, S. Hornauer and T. Kiefer, Fuel Cells, 17 (4), 508-516 (2017).

6. J. Nielsen, Å. H. Persson, B. R. Sudireddy and J.T.S. Irvine, K. Thydén, J. Power Sources, 372, 99-106 (2017).

7. A. Persson, "Effective corrosion protection coatings for metal supported solid oxide fuel cell FeCr composite based anodes", in preparation.

8. J. Nielsen, T. Klemensø, P. Blennow, J. Power Sources, 219, 305-316 (2012).

9. J. Nielsen, P. Hjalmarsson, M. H. Hansen, P. Blennow, J. Power Sources, 245, 418428 (2014). 